\title{
1 A geografia literária de Macunaíma: Protocolos de leitura e a hegemonia do modernismo paulista (1922-1928)"
}

Enio Passiani **

Este artigo é uma versão consideravelmente ampliada da comunicação oral apresentada, com 0 mesmo título, no $38^{\circ}$ Encontro Anual da Anpocs, em Caxambu (MG), em 2014.

Professor Adjunto do Departamento de Sociologia da Universidade Federal do Rio Grande do Sul (UFRGS).
Resumo: A construção da hegemonia do modernismo paulista deu-se pelo trabalho de consagração de intelectuais posteriores à Semana de 1922, o início oficial do movimento no Brasil; e graças ao empenho do grupo paulista, capitaneado por Mário de Andrade, em oficializar sua posição como a mais legítima representante do modernismo nacional. $\mathrm{O}$ exercício de autoconsagração foi necessário devido às fraturas que revelavam a existência de muitos movimentos modernistas no país envolvidos na disputa por um certificado de autenticidade. Em meio às dissidências, os vários grupos adotaram como estratégia de combate a formulação e a divulgação de protocolos de leitura que se revelaram eficazes no estabelecimento de convenções literárias em detrimento de outras. Dentre os protocolos destaco a importância do romance Macunaíma. Espaço de experimentações estilísticas, o livro serviu também como manifesto implícito das próprias posições estéticas e políticas do autor, arremate literário de um projeto intelectual elaborado ao longo dos anos.

Palavras-chave: Modernismo - Modernismo Paulista - Mário de Andrade - Macunaíma - Protocolos de Leitura

\begin{abstract}
The construction of the São Paulo modernist hegemony was the result of the consecration work done by later intellectuals to the Week of 1922, the official start of the movement in Brazil; and thanks to the commitment of specific São Paulo group, led by Mario de Andrade, in his official position as the most legitimate representative of the nationa modernism. The exercise of self consecration was necessary due to fractures occurring within the movement itself, generating various group involved in the dispute by a certificate of authenticity. Amid disagreements, various groups have adopted, as a strategy of combat, the formulation and dissemination of reading protocols that have proved effective to establish literary conventions over others. Among the protocols, I emphasize the importance of the novel Macunaíma: stylistic experimentation space, the book also served as implicit manifesto of aesthetic and political views of the author, literary final touch of an intellectual project developed over the years.
\end{abstract}

Key words: Modernism - São Paulo Modernism - Mário de Andrade Macunaíma - Reading Protocols 


$$
\text { I. }
$$

O poeta municipal discute com o poeta estadual qual deles é capaz de bater o poeta federal. Enquanto isso o poeta federal tira ouro do nariz. - Carlos Drummond de Andrade, Política literária

Por que o modernismo paulista se destaca frente outros modernismos nacionais? Quais fatores permitiram que o modernismo de São Paulo passasse a representar, de acordo com extensa fortuna crítica, quase única e exclusivamente, o modernismo nacional? A ponto de, até, prescindir do adjetivo que qualificasse sua origem; ao contrário dos demais, que se tornariam praticamente órfãos sem uma determinação de lugar. Daí se falar em um modernismo mineiro, carioca, gaúcho ou nordestino, ao passo que o paulista tornou-se, hegemonicamente, o modernismo. Apesar de se reconhecer a existência de vários modernismos no Brasil, historicamente a referência, creio que ainda nos dias de hoje, é a de São Paulo. Uma hipótese plausível é que, já em 1922, é esta cidade que se transforma, como um ímã, num centro de atração de intelectuais e artistas de outras regiões do Brasil que também ambicionam participar dos movimentos de renovação estética, e é a capital paulistana a capital da vanguarda. E quando afirmo que a cidade se tornou essa espécie de ímã, não quero com isso dizer que em São Paulo vários desses intelectuais fixaram residência, como acontece com o Rio de Janeiro. Não. O que quero afirmar é que a capital paulista vinha reunindo, desde final do XIX, as condições materiais que permitiram, nas primeiras décadas do $\mathrm{XX}$, um intenso tráfego de ideias que, por sua vez, motivou muitos debates, encontros, desencontros, querelas, afirmação de identidades intelectuais e estéticas.

Por isso, a explicação acerca da hegemonia paulista no desenvolvimento do modernismo nacional não pode se limitar a uma suposta superioridade estética, tampouco num grau absolutamente elevado e inédito do movimento vanguardista de São Paulo, que tem, como se sabe, na Semana de Arte Moderna seu início oficial (Moisés, 2001, p. 33).

Responder a tais questões, ou pelo menos sinalizar possibilidades de resposta exige discutir como se deu a construção do predomínio do campo artístico paulista sobre o campo artístico nacional no que se refere ao tema "modernismo". Muitos autores já se debruçaram sobre o tema (Miceli, 1979; Pontes, 1998; Hardman, 1996, 2000), interrogando criticamente o significado do modernismo de São Paulo para a história da literatura brasileira ao desvelar as ligações de alguns de seus representantes com as elites locais e com o Estado, ao trazer à tona todo o trabalho de continuação dos critérios modernistas (de São Paulo) de validação estética e literária por parte de historiadores e críticos de arte e literatura posteriores ao movimento modernista, ou, ainda, ao revelar que a nascente do modernismo no Brasil é anterior à "geração heroiica" de 1922, e não se resume a apenas uma, mas são 
diversas espalhadas geograficamente. De acordo com Hardman (1996), mesmo antes dos modernistas paulistas, outros intelectuais se empenharam em redescobrir o país, só que, no caso paulista(no), tal empreitada foi transformada em programa, por esforço dos herdeiros do modernismo, mas também por iniciativa dos próprios modernistas. Nesse processo de imposição e canonização, a vanguarda da pauliceia foi transformada, de modo ambicioso e com êxito, em sinônimo de identidade nacional, apoiada no mito da “comunidade espacio-temporal” (Hardman, 1996, p. 303).

Nesse sentido, sob a noção de vanguarda, ocultaram-se processos culturais relevantes em gestação desde a primeira metade do século XIX. E talvez o principal efeito dessa operação de ocultamento foi justamente a exclusão daquelas manifestações que não se enquadravam nos cânones de 1922. E com razão indaga Hardman:

Modernismo, qual? Dos artistas de 1922 ou de 1900 ? Da geração de 1930 ou de 1870? Dos comunistas de 1922 ou do movimento operário socialista e libertário das décadas precedentes? Dos arquitetos acadêmicos ou dos engenheiros de obras públicas? Dos 'tenentes' dos anos 20, dos abolicionistas e republicanos de meio século antes? Dos poetas metropolitanos ou dos seringueiros do Acre? Dos fios telegráficos da Comissão Rondon ou dos índios rebeldes? De Mário e Oswald de Andrade ou de Mário Pedrosa e Lívio Xavier? Da revolução 'técnica' ou da revolução 'social'? Dos nacional-integralistas ou dos bolchevistas? Do Manifesto Antropófago ou do Primeiro de Maio? (Hardman, 1996, p. 303).

Este trabalho pretende tratar de algumas dessas dúvidas, mas numa direção diversa e deter-se sobre o momento de gestação de certos protocolos de leitura que, num primeiro momento, lançam as bases dos critérios modernistas de classificação e, num segundo, encontram sua realização mais bem acabada em termos estéticoliterários, praticamente consolidando tais protocolos, inaugurando uma tradição (inclusive crítica) que finca profunda e firmemente suas raízes no solo artístico e intelectual brasileiro. Para ser mais especifico, este artigo se deterá sobre um dos mais poderosos protocolos de leitura já formulados nos anos heroicos do modernismo nacional e paulista: a rapsódia romanesca Macunaíma, de Mário de Andrade.

Tentar-se-á entender as questões acima enunciadas a partir da associação entre o processo de modernização da cidade, a importância política de São Paulo e a modernidade estética, pois só assim, creio, se permitirá vislumbrar como a ampliação de um mercado de bens simbólicos ensejou o desenvolvimento de certas formas estéticas. Ou, noutros termos, tentar-se-á captar a transformação das experiências sociais em expressões estéticas.

II.

São Paulo, entre 1889 e 1930, passa por um certo impulso desenvolvimentista e modernizador que causa impacto nos meios materiais de produção cultural, que, por sua vez, afetam as formas estéticas. Nesse período ocorre um aumento significativo do número de jornais e suas tiragens; o desenvolvimento do mercado editorial fatos estes que contribuem para a profissionalização do trabalho

Dossiê Literatura e Memória

Arquivos do CMD, Volume 3 N.2. Ago/Dez 2015 
intelectual -; a modernização técnica, associada à industrialização da cidade, afeta os modos de impressão, acelerando a produção e inaugurando novos padrões tipográficos que não deixaram de impactar a própria linguagem literária; o intenso movimento migratório, cuja influência não se fez sentir apenas na indústria e no comércio, mas trouxe igualmente novas práticas e novos hábitos culturais - além de contribuir para a pluralização cultural de São Paulo -; um certo avanço do mercado de bens de consumo, também ligado ao crescimento comercial e industrial, estimula o progresso de novas áreas de atuação, como a publicidade, cujas técnicas narrativas serão aproveitadas pelos modernistas na elaboração dos protocolos de leitura.

Os modernistas de modo geral, e os paulistas em particular, constroem um mercado narrativo peculiar, em que convivem diversos gêneros, desde o mais nobre, a poesia, até os mais, digamos, bastardos, como os textos-manifestos - podemos incluir na categoria "manifesto" as revistas modernistas, ainda que obviamente elas não configurem propriamente um gênero - e as crônicas, que constituem um espaço privilegiado para elaborar e propalar os protocolos de leitura, dada a maior circulação e abrangência dos jornais, e um lugar para o exercício do trabalho intelectual. Os manifestos, por seu turno, embora tenham na dimensão estética o princípio ordenador, correspondem a uma espécie de tradução, no campo artístico e intelectual, da modernização das sociedades burguesas (inclusive latino- americanas); e constituem, aponta Williams, o emblema das escolas que se auto-definem e se auto-promovem (Williams, 2005, p. 180).

A potência do mercado narrativo paulista, dotado de uma cultura impressa dinâmica - quando comparada a outros mercados narrativos nacionais - confere aos modernistas uma grande capacidade para exportar seus protocolos - além da chance de incorporar e transformar os avanços técnicos das mídias da época em linguagem literária. A hegemonia paulista durante a República Velha, além de econômica e política, ganha, a partir de um determinado momento, sua versão cultural e literária. Tal hegemonia pretende se impor de tal modo a fim de relegar para um segundo nível os demais modernismos, num procedimento que apagaria as diferenças culturais regionais e locais, fazendo do movimento modernista de São Paulo quase um sinônimo de identidade nacional. Esse trabalho de imposição não se deu apenas por esforço dos críticos e historiadores literários posteriores ao modernismo, mas também por energia despendida pelos próprios participantes e artífices do modernismo paulista. Antônio Celso Ferreira (2004) já chamou a atenção para o fato de que, no período que vai de 1870 a 1940 , configurou-se uma visão épica sobre São Paulo e o paulista, expressa num amplo conjunto de textos que circularam na região - e, acrescento, até para além dela. E o movimento é considerado por Ferreira como "um ponto de inflexão privilegiado para a análise dessa produção textual, na medida em que atualizou e deu novos contornos ao imaginário regional" (Ferreira, 2004, p. 81). Nesse sentido, a literatura modernista 
${ }^{1}$ Aron e Viala explicam : "Toute société repose em effet sur des communautés plus ou moins bien partagées de valeurs, tant dans l'ordre politique (démocratie vs pouvoir totalitaire, par exemple) que dans l'ordre de la morale social et privée, ou dans l'ordre des goûts. Le but d'une sociologie du littéraire est, en fin de compte, de rendre compte de ces jeux de valeurs (...). Faire une sociologie des auteurs, des lecteurs, des critiques, etc. permet de donner une description précise des groupes qu'ils constituent, mais risque de rester à la lisière de ce qui est l'enjeu social crucial: le jeu des valeurs et des adhésions à des valeurs - et donc, réciproquement, des rejets d'autres valeurs possibles" (Aron \& Viala, 2006, p. 58).

${ }^{2}$ A relação entre as disputas simbólicas e aquelas de ordem política e/ou econômica raramente se mostram de modo explícito na própria obra. O mais comum é que os jogos que se desenrolam em outras esferas ganhem, digamos, uma tradução estética, dificultando, provavelmente, a sua apreensão. correspondia aos anseios de um "alargamento da identidade cultural paulista" (Idem: 107) a ponto de confundir-se com a identidade nacional; a ponto de estabelecer o modernismo paulista como modernismo nacional, criando uma imagem, que conserva ainda parte de sua força, dos intelectuais de São Paulo como "heróis civilizadores", "artífices da modernização e fundadores da cultura nacional" (Lahuerta, 1997, p. 100).

O poder político e econômico de São Paulo, como se disse, obteve legitimação na esfera estritamente intelectual, e o campo artístico paulista acabou levando nítida vantagem na concorrência com outros campos, locais e/ou regionais, tendo sido entronizado como campo intelectual nacional - pode-se afirmar que havia, sim, um intercâmbio cultural à época, todavia, o fluxo e as trocas culturais, ao que parece, tinham São Paulo como entroncamento obrigatório, tornando a cidade uma área de atração irresistível, senão de pessoas, de debates, ideias e movimentos culturais, e por isso sede dos movimentos de vanguarda no Brasil.

\section{III.}

Vários autores lembram que não é mais possível desvincular a proposta modernista de um projeto político mais amplo de construção de uma identidade paulista (Sevcenko, 2004; Schwarcz, 2004; Ferreira, 2002, 2004), estendendo, portanto, a hegemonia de São Paulo para o campo cultural, fechando um círculo que já englobava a posição dominante do estado nos terrenos político e econômico. O desejo de a elite paulista de se fazer representar na esfera da cultura motivou a criação de várias instituições culturais, como o Instituto Histórico e Geográfico de São Paulo (IHGSP) (Schwarcz, 2004, p. 169), o Pensionato Artístico de São Paulo (Camargos, 2001, p. 66); o patrocínio de atividades culturais, como a Semana de Arte Moderna; o mecenato promovido por uma parcela culta da burguesia paulistana, como são os casos de Freitas Valle e Paulo Prado.

As disputas entre as várias facções modernistas e, consequentemente, entre as várias cidades que as abrigavam, torna evidente que a literatura não se limita à sua dinâmica interna, como se ela fosse, em si mesma, seu único princípio de constituição. A literatura, bem como qualquer outra manifestação artística, enquanto fato social, contribui para reforçar a autoridade que fundamenta a dominação, não somente simbólica, mas também econômica e política. Viala e Aron assinalam que o objeto primordial de uma sociologia literária repousa no estudo do que chamam de "efeitos de adesão" (Aron \& Viala, 2006, p. 58) ${ }^{1}$. Tal adesão, e os efeitos que ela provoca, está relacionada a um jogo de interesses estéticos que não deixa de expressar interesses outros que estão além do campo simbólico ${ }^{2}$. A contribuição da literatura para a reprodução e cristalização - ainda que temporária - do poder e da dominação torna-se tanto mais eficaz quanto mais essa literatura torna-se conhecida e reconhecida. Nota-se, então, um duplo trabalho, independentes, mas interligados: a construção da legitimidade e da hegemonia literárias, principalmente a partir da

Dossiê Literatura e Memória

Arquivos do CMD, Volume 3 N.2. Ago/Dez 2015 
definição dos cânones; e a construção da legitimidade e da hegemonia políticas. É aí que a sugestão de Aron e Viala sobre os “efeitos da adesão" ganha sentido, pois é possível traçar a adesão dos interesses estéticos aos interesses políticos. O processo de transformação de uma literatura regional em literatura nacional corresponde ao processo de definição oficial da literatura oficial de uma unidade política, que, no caso aqui discutido, pretende tornarse equivalente à unidade política nacional. A esse respeito, é pertinente a seguinte observação de Pierre Bourdieu:

\begin{abstract}
A língua oficial está enredada com o Estado, tanto em sua gênese como em seus usos sociais. É no processo de constituição do Estado que se criam as condições da constituição de um mercado linguístico unificado e dominado pela língua oficial: obrigatória em ocasiões

e espaços oficiais (escolas, entidades públicas, instituições políticas etc.), esta língua de Estado tornase a norma teórica pela qual todas as práticas linguísticas são objetivamente medidas (Bourdieu, 1998, p. 32).
\end{abstract}

O trecho acima mereceria apenas alguns reparos e atualizações em relação aos objetivos propostos por este trabalho: no lugar de "língua" leia-se "língua literária" (ou simplesmente "literatura"); se Bourdieu preocupava-se com a formação do Estado nacional francês, aqui se trata da expansão do poder (político, econômico e cultural) de um estado - e de uma cidade - sobre a nação, num determinado momento histórico; ao invés de se falar em "mercado linguístico", esta pesquisa trata de "mercados narrativos"; por fim, como corolário da última retificação do texto de Bourdieu acima citado, a expressão "práticas linguísticas" cederá lugar à "práticas literárias". Excetuando-se, pois, os termos, o sentido se mantém: a legitimação de uma língua ou de uma literatura significa muito mais que a legitimação de uma língua ou literatura; ela expressa e revela uma dominação política, que, por sua vez, é reproduzida pelas instituições capazes de impor o reconhecimento universal de uma língua ou literatura dominante.

Nesse sentido, o modernismo paulista representava mais um capítulo, importante decerto, dessa "epopeia bandeirante" (Ferreira, 2002, p. 267 e ss.). A literatura mostrou-se, pois, ao longo da República Velha - até a Revolução de 30 -, uma peça-chave na delimitação das fronteiras (geográficas e simbólicas) e na construção de identidades, particularmente a de São Paulo. O estado econômica e politicamente mais poderoso da nação, por meio dos seus intelectuais e instituições culturais, começava a construir uma representação de si mesmo: uma terra de gigantes, os bandeirantes, desbravadores corajosos, destemidos povoadores do interior do país, terra que traduzia a própria alma mestiça brasileira, já que no solo paulista encontrava-se uma "mistura épica das raças" (Andrade, Mário de apud Ferreira, 2004, p. 102-103.). E a literatura modernista em muito contribuiu para a definição de uma ideia de "região", seja em relação ao papel do estado na condução dos destinos do país, seja, mais especificamente, em relação ao papel da literatura modernista de São Paulo diante da literatura nacional. O regionalismo paulista pretendia impor-se aos demais justamente negando seu caráter regional, local, travestindo-se de "nacional”. A partir do momento que São Paulo - representado, obviamente, por

Dossiê Literatura e Memória 
${ }^{3} \mathrm{O}$ regionalismo, afirma Bourdieu, nada mais é do que "um caso particular de lutas propriamente simbólicas" levadas a cabo po agentes individuais ou coletivos, e que tem como objetivo "conservar ou transformar as relações de força simbólicas e seus lucros correlativos, tanto econômicos quanto simbólicos" (Bourdieu, 1980, p. 69). A estes últimos acrescentaria também os dividendos políticos. suas elites - pretendeu deixar de ser "apenas" São Paulo para ser “o” Brasil, São Paulo tornou-se mais paulista e mais paulistano do que nunca, já que, por meio da elaboração de tais representações, o estado, e mais precisamente sua capital, firmava sua identidade e apresentava suas reais ambições políticas, econômicas e artísticoliterárias ${ }^{3}$.

A instituição da literatura legítima - e, por conseguinte, de um poder legítimo - depende da formação e desenvolvimento de um mercado de bens simbólicos, com seus agentes e agências sociais específicos, responsável pela institucionalização da "autoridade", da "referência obrigatória" e do "uso correto" - neste caso trata-se do "uso correto" do programa estético do modernismo paulista -, reproduzindo uma literatura modernista que se pretende uma literatura modernista oficial.

\section{IV.}

Wilson Martins escreve que a Semana de 1922 foi menos um ponto de partida do que o "coroamento de todo um processo intelectual" (Martins, 1977, p. 16), dado que, segundo ele, o modernismo já estava maduro numa certa camada dos intelectuais brasileiros. Maturidade atingida graças a uma série de experimentos estéticos levados a cabo anteriormente, junto à imprensa e revistas - algumas delas com os próprios modernistas à frente. A Semana representou a declaração pública de uma ruptura que já vinha sendo ensaiada e propalada anteriormente por um grupo ainda pequeno, mas entusiasmado, de jovens escritores insatisfeitos com aquilo que considerava literariamente ultrapassado. As crônicas e artigos que inundaram o periodismo paulistano antes da declaração de independência estética de 1922 visavam atacar os representantes e defensores de uma literatura pomposa, acadêmica, pura imitação dos modelos exteriores, principalmente europeus e, ao mesmo tempo, começar a difundir as regras e princípios estéticos que entendiam estar de acordo com as necessidades e exigências do país. Esse foi o primeiro front de batalha modernista, o que indicava, de acordo com Mário da Silva Brito (Brito, 2001, p.: 12), que até 1921, e talvez até alguns poucos anos depois da Semana, o grupo se encontrava coeso e unido contra os próceres do passadismo.

Mesmo após a Semana de Arte Moderna, a divulgação modernista não pôde estancar. Ao contrário, ela continuou intensamente e sob novas formas. E basicamente por duas razões: primeiro, ela não teve a repercussão esperada (Cardoso, 1983, p. 39) e, talvez por isso, jornais tradicionalmente conservadores, no campo político e cultural, como $O$ Estado de S. Paulo, não só não demonstraram hostilidade em relação ao evento, como trataram a arte modernista até com certa simpatia (Martins, 1977, p. 54) - há que se considerar também o apoio que o movimento recebeu dos setores mais tradicionais da elite local e que tinha alguns jornais da cidade como porta-vozes. O segundo motivo pelo qual os modernistas não pararam sua intensa campanha em prol da estética moderna foi a própria heterogeneidade do movimento, marcado por

Dossiê Literatura e Memória 
inúmeras divergências internas. Alguns historiadores da literatura (Martins, 1977; Moisés, 2001) costumam apontar o ano de 1924 como a data que estabelece a radical divisão dum movimento outrora unido. Ao que parece, o primeiro tempo da disputa - que havia gerado a coesão do grupo -, contra os "antigos", já havia passado; daquele momento em diante a contenda era interna, com muitos grupos se batendo pela liderança do modernismo. Como consequência de um clima assim rebelde, as várias facções modernistas e seus porta-vozes desandaram a redigir prefácios doutrinários, manifestos, crônicas e artigos defendendo sua posição contra tantas outras, todas elas em busca de legitimidade. Essas duas razões, conjuntamente, estimularam a redação de inúmeros programas estéticos - daí a inflação da produção de protocolos que tentavam explicar e divulgar uma determinada versão do movimento junto a um restrito público leitor, formado pelos possuidores de hábitos literários e, dentre estes, aqueles que compunham a intelligentsia paulistana e, para além dela, nacional.

V.

Dentre os protocolos de leitura que continuaram a ser produzidos e escoados ao longo de toda a década de 1920 a fim de fixar uma de suas formas como mais autêntica e, por isso, definitiva, destaco o romance rapsódico Macunaíma, de Mário de Andrade. Nele encontramos aquela que é, talvez, a mais radical experimentação estilística do modernismo nacional dos anos 20 , uma espécie de realização, programa e síntese de um projeto que tentava alinhavar ideais estéticos e políticos de parcelas das elites culturais e políticas de São Paulo que buscavam, naquele momento, entre 1926 e 1928 - período que compreende a redação de Macunaíma, suas várias correções e sua publicação -, no mínimo manter e, se possível, alargar a influência política e cultural paulista justamente num momento de declínio de sua importância.

A historiadora Maria Inez Machado Borges Pinto alerta para as representações da cidade como locus da modernidade e da superação do atraso presentes na obra daquele modernismo paulista capitaneado por Mário, e criando aquilo que chamou de “configuração do regionalismo paulista” (Pinto 2001, p. 436-437), a imagem de uma cidade que conjugava, melhor que qualquer outra, "os valores da brasilidade e da modernidade" (Pinto, 2001, p. 437). Embora, portanto, certo modernismo paulista procurasse superar todas as outras formas de regionalismo, considerados passadistas e antimodernos, colocava, paradoxalmente, em seu lugar, um outro tipo de regionalismo, este sim mais afeito às ambições de fatias das elites políticas e literárias locais.

Outra historiadora, Mônica Raisa Schpun, disseca a paisagem urbana e moderna de São Paulo na obra mariodeandradiana. Em relação especificamente à Macunaíma, escreve:

Dossiê Literatura e Memória 


\begin{abstract}
Esse olhar sobre a vida urbana que tende a humanizar suas transformações, seus ritmos, refere-se, antes de mais nada, a uma maneira particular de ver e de representar a modernidade paulistana. Trata-se de uma reflexão que, a meu ver, encontra seu momento mais eloquente em Macunaíma. Pois ainda que o protagonista tenha nascido "no fundo do matovirgem", filho da "índia tapanhumas", grande parte de suas aventuras passa-se em São Paulo (Schpun, 2003, p 28).
\end{abstract}

Ainda de acordo com a autora acima mencionada, dos 17 capítulos e um epílogo que compõem a obra, 11 se desenrolam em São Paulo (do $5^{\circ}$ ao $15^{\circ}$ ), sem falar das referências esparsas feitas à cidade noutros momentos da rapsódia. Schpun foi uma das primeiras pesquisadoras a chamar a atenção para as representações de São Paulo em Macunaíma e à importância que a cidade assume no corpo da narrativa. Portanto, o caminho que se tomará a seguir propõe hipóteses de leitura que retomam algumas de suas sugestões, as redirecionam e as complementam a partir de uma sociologia literária que tem Pierre Bourdieu e Raymond Williams como principais referências. E tais hipóteses de leitura sociológica se concentrarão em dois momentos do livro: o capítulo 9 (Carta pras icamiabas), justamente o capítulo que divide a obra em duas metades e fartamente citada pela fortuna crítica como momentochave da narrativa (Bosi, 1988; Lopez, 1988; Fonseca, 1988; Souza, 1988) e o episódio da luta de Macunaíma contra o gigante Venceslau Pietro Pietra, quando ocorre a recuperação da pedra mágica muiraquitã, o Graal do (anti) herói (Souza, 2003), após a longa jornada que constitui, de fato, o núcleo do romance.

\section{VI.}

De acordo com a crítica especializada (Bosi, 1988; Souza, 2003), Mário de Andrade, em Macunaíma, adota a técnica da bricolage, tal como ocorre com as narrativas míticas, para agrupar elementos supostamente díspares, afastados no tempo e no espaço, ao núcleo da narrativa: a busca pela pedra mágica muiraquitã, como já se disse. Carta pras icamiabas, num certo sentido, não deixa de representar uma espécie de capítulo-modelo de tal técnica de colagem. Nele, afirma Bosi, visualizamos o "moderno da perspectiva crítica e o arcaico da composição rapsódica" (Bosi, 1988: 176). O capítulo, todo ele epistolográfico, sintetiza à perfeição toda e dificuldade que se encontra em definir a identidade simbólica e plural do (anti) herói - expressa, por sinal, no subtítulo dado por Mário ao livro, heroi sem nenhum caráter -, uma vez que sua escrita oscila entre elementos eruditos, arcaísmos da língua e o que se consideraria erros do ponto de vista da linguagem culta. Nesse sentido, "Carta pras...", considera Bosi, é recheada de "intenções paródicas", subvertendo o "academicismo bandeirante" no registro irônico e cômico, mas, lembremos, sem dele abrir mão. É como se Mário, ao invés de simplesmente descartar o academicismo elitista bandeirante, se preocupasse em atualizar tal "bandeirantismo" paulista noutros termos, talvez mais "solto", livre da rigidez acadêmica, mais "moderno", enfim, mas sem deixar de ser paulista jamais. Nessa mesma linha de raciocínio lembro as

Dossiê Literatura e Memória 
observações de Telê Porto Ancona Lopez, certamente a maior especialista brasileira sobre Mário de Andrade, a respeito de "Carta pras...":

Peça no conflito progresso x civilização, conflito que mal percebe, Macunaíma, o primitivo, adota o discurso do poder, linguagem escrita. Adota-o, no entanto, à sua moda. Se, por um lado, considera válidos e recolhe todos os estilos, tentando se expressar em português castiço, empolado, tendo por finalidade pedir dinheiro a suas súditas, por outro, fru $o$ ato de escrever, assim como frui o de contar, e a tal ponto que nele imprime uma de suas características básicas, o erotismo. A "Carta pras icamiabas" tem avesso e direito. No qui pro quo, na ironia que se irmana à ingenuidade na exaltação hiperbólica de certos valores do mundo tecnizado, a sátira toma corpo. Visa, mais que a Macunaíma, o dito mundo da civilização e do progresso industrial (Lopez, 1988, p. 272).

Sublinha-se, aqui, que o discurso do poder adotado por Macunaíma é justamente a linguagem escrita, instrumento de batalha dos modernistas contra as correntes literárias consideradas ultrapassadas, mormente o realismo e o naturalismo, e igualmente contra as muitas vertentes internas ao próprio modernismo. Mário, por meio de Macunaíma, procura instituir modos de ler e, mais, modos de fazer literatura que identificassem certo modernismo paulista e o colocassem acima dos demais: a mistura radical dos estilos, a aproximação da literatura à narrativa oral, a sensualidade, uma autêntica "cultura de mescla" que não deixa de remeter, ainda que de modo cifrado, à própria cultura de São Paulo. E a cidade ainda é lembrada e exaltada pelo seu desenvolvimento tecnológico, por seu progresso, pelo avanço industrial, tudo isso, é claro, temperado pelo modernismo defendido por Mário, que, por intermédio da sátira e da ironia, romperia com a sisudez da modernização; retocaria o acinzentado da urbe com tons mais coloridos e alegres; defenderia, por meio de Macunaíma, o direito à preguiça na terra do trabalho; misturaria o avesso e o direito num esforço de atualização da cultura paulista e paulistana a fim de recolocar a cidade como locomotiva não apenas da civilização brasileira, mas como locomotiva da civilização modernista brasileira.

As contradições "macunaímicas", poderiam argumentar alguns, relativizam o peso e a importância de São Paulo e dos modernismos que aqui se desenvolvem, pois acabam colocando a cidade e tudo que a ela diz respeito sob suspeita, sob crítica. A hipótese que se apresenta aqui, no entanto, caminha em direção oposta: as contradições do personagem, inclusive aquelas que dizem respeito à vida urbana e tecnicizada da cidade grande, representam uma resistência "à lógica racionalista europeia" (Lopez, 1988, p. 275) e preservam certo "pensamento selvagem", que, repito, antes de negar, ressignifica, atualiza e reafirma o papel que São Paulo tem na condução da nação. Nesse sentido, São Paulo, berço de levas e levas de imigrantes, converte-se, mais que outras cidades brasileiras, num lugar de encontro e trocas culturais, uma verdadeira Babel moderna que integra e conjuga dicções culturais de ordem variada. Em São Paulo desenvolve-se o que Beatriz Sarlo chamou de "cultura de mescla" a propósito de Buenos

Dossiê Literatura e Memória 
${ }^{4}$ A respeito do fluxo migratório para São Paulo e suas implicações sociais, políticas, culturais e econômicas, ver, entre outros: Alvim, 1986; Carelli, 1995; Cenni, 2003; Diegues Jr., 1964; Ferreira, 2002; Lobo, 2002; Fausto, 1991, 1995; e Oliveira, 2006.
Aires. Macunaíma, o livro, não deixa, pois, de apresentar uma rapsódia que expressa a própria cidade de São Paulo, pois:

$$
\begin{aligned}
& \text { “(...) recolhe e integra, no estilo, como se sabe, as } \\
& \text { vozes e as 'frases' de todas as camadas da sociedade e } \\
& \text { de todas as regiões do Brasil; a língua antiga, os } \\
& \text { estrangeirismos, os barbarismos, a gíria, tudo enfim } \\
& \text { que está no povo, até as referências literárias" } \\
& \text { (Fonseca, 1988, p. 280) }{ }^{4} \text {. }
\end{aligned}
$$

É como se o "caráter mestiço da escrita" (Idem, ibidem) da carta traduzisse o caráter mestiço da capital paulista.

N'A carta pras Icamiabas, Macunaíma, o personagem, seria, ao mesmo tempo, a encarnação da cultura de mescla que se desenvolve em terras paulistanas e a crítica aguda, em tom irônico, ao academicismo, à cultura erudita daquelas elites que procuram se distanciar e se esquecer das manifestações mais populares: "Pedante, pretensioso, citando os clássicos, Macunaíma dá vazão a sua cultura semi-letrada, e acoberta com a linguagem livresca e as alusões eróticas o principal objetivo da carta (conseguir dinheiro), crivando de subentendidos todo o discurso" (Fonseca, 1988, p. 279). Sem as trocas culturais - que caracterizam o ambiente paulista de início do século XX - é o discurso acadêmico e pedante que se torna superficial, vazio, servindo apenas de máscara que acoberta os interesses das elites. De acordo com Fonseca (1988), Macunaíma se apropria da linguagem do colonizador para a ele se igualar e se impor diante de suas súditas; todavia, continua a autora, a língua mal aprendida apenas trai sua origem mestiça. Uma perspectiva assim realça a postura crítica do autor, que por meio de seu anti-herói coloca sob suspeita a cultura livresca e elitista. Mas, o que se pretende argumentar aqui é que a rapsódia de Mário de Andrade também é uma máscara que encobre um projeto político e estético de uma parcela ilustrada da elite paulistana que pretende manter São Paulo como a "locomotiva da nação", preservando (ou procurando preservar) sua condição hegemônica no cenário nacional. No fundo, Macunaíma apresenta São Paulo como alternativa ao status quo político e cultural do país, ainda atrasado e dependente.

Se há na carta o uso da língua culta como instrumento de dominação sobre as súditas analfabetas, desconhecedoras da língua escrita, se há o uso da cultura letrada e erudita como forma de imposição, há que se lembrar que o episódio nos mostra o uso irônico da língua culta, como se ela se denunciasse a si mesma ao descarregar toda sua verborragia. Um uso assim da linguagem reafirma a proposta subversiva não apenas da carta, mas do modernismo preconizado por Mário e, mais uma vez, reafirma a posição central de São Paulo na reavaliação e redirecionamento da cultura nacional. Lugar do encontro das culturas e das temporalidades díspares, cruzando linguagens e conjugando tradição e modernização, a cidade torna-se símbolo de originalidade cultural e das potencialidades que todas essas misturas ensejam. O capítulo dedicado à carta pras Icamiabas não faz menos que apontar São Paulo como o caminho de uma civilização modernista. 
Como se disse acima, a vivência cotidiana dos imigrantes em nova terra, São Paulo, levou à fusão de vários elementos culturais, encurtando o caminho para um pluralismo cultural que possui diferentes origens étnicas. No entanto, o processo migratório não se limita aos aspectos mais saudáveis e positivos da interação social, ao contrário, a imigração é crivada de elementos contraditórios. Por isso, nos alerta Octavio Ianni, é preciso ter muito cuidado em relação a um discurso oficial que procura estabelecer apenas essas experiências saudáveis da imigração (Ianni, 2004, p. 138), processo este que também suscitou tensões e choques culturais. Em suma, a assimilação não ocorre de modo tranquilo, daí a necessidade de encarar a imigração como elemento dinâmico no conjunto da sociedade para se evitar sua mitificação (Ianni, 2004, p. 150-152).

Boris Fausto chama a atenção também para as vantagens ideológicas de se adotar a perspectiva do pluralismo cultural, baseado na crença do inter-relacionamento pacífico entre a sociedade nacional e as várias etnias, incluindo aí os descendentes dos imigrantes, e destas entre si (Fausto, 1991). Parecia fundar-se, assim, uma "nova sociedade paulista", multi-étnica e integradora, que recebia de braços bem abertos a todo e qualquer estrangeiro. Talvez se possa falar, sim, numa sociedade multi-étnica e integradora, mas a integração, que de fato ocorreu, não se deu por caminhos fáceis. Havia, ao mesmo tempo, afirma Fausto, uma atração e uma ironia dos paulistas pelos imigrantes (Fausto, 1991, p.
40) que muitas vezes nada mais era do que a expressão do preconceito, principalmente por parte das elites paulistanas. A situação que se apresentava, então, era ambígua. Havia o preconceito, manifesto de muitas formas - como a irritação contra a imprensa de língua estrangeira e escolas de colônias ou os acontecimentos anti-italianos de 1892-1896 (ver Hall, 2004) -, mas que não foi o suficiente para impedir a ascensão social e integração do elemento estrangeiro:

Em resumo, seria absurdo negar a existência do preconceito e da discriminação que feriu pessoas, barrou determinados caminhos. Pensada porém a questão em termos sociais mais amplos, tudo indica que os limites simbólicos ou materiais impostos aos grupos imigrantes foram insuficientes para impedir sua ascensão social e seu papel na remodelagem da sociedade paulista (Fausto, 1991, p. 52).

Os ataques vindos da elite ilustrada de São Paulo, que tinha como importante foco o curso de Direito do Largo do São Francisco, preconizavam que os imigrantes estariam apenas preocupados em fazer fortuna, despreocupados com a ordem cívica e moral da sociedade, logo, aos olhos "ilustrados", sua presença representava uma ameaça à existência da comunidade nacional. Os "velhos paulistas", a elite mais tradicional de São Paulo, além de ver seus interesses materiais em risco devido à concorrência que os imigrantes mais bem sucedidos podiam oferecer, acreditava numa certa "pureza" étnica e enxergava a mistura racial e cultural como um perigo para sua própria história futura. Explica, dessa forma, a 
${ }^{5}$ Para uma discussão sobre a valoração negativa dos imigrantes em geral e os judeus em particular: Grün, 1995.

${ }^{6}$ Embora utilize as expressões: "os italianos" ou "o grupo italiano", reconheço sua perigosa generalização, uma vez que havia no interior dos vários grupos étnicos, e entre os italianos não seria diferente, divergências e distinções. Sobre as diversas "Itálias" no Brasil: Alvim, 1986. interdição, por um tempo relativamente longo, à participação política do imigrante.

Se, por um lado, nunca houve em São Paulo guetos étnicos, por outro havia uma baixa aceitação a certos grupos 5 - no interior destes havia subgrupos, alguns mais bem aceitos que outros devido à condição socioeconômica e cultural e, às vezes, em razão de seu lugar de origem -, o que resultou num processo gradual de assimilação, que, de acordo com Hall, levava, em média, três gerações (Hall, 2004, p. 123). Ainda assim, o grupo italiano, maior contingente de imigrantes em São Paulo, foi o mais rapidamente assimilado (Hall, 2004, p. 126) ${ }^{6}$.

De todo modo, a participação dos imigrantes na vida paulistana oferecia novos horizontes culturais, inclusive no campo literário. Se assim é, poderíamos perguntar como o fenômeno da imigração e o imigrante, com destaque para o de origem italiana, já que não era só o maior grupo, mas também aquele mais rapidamente incorporado à vida da cidade de São Paulo, foram apanhados pela literatura da época, especialmente modernista. Para Lúcia Lippi Oliveira, “(...) a realidade social da imigração italiana parece não encontrar espaço equivalente na literatura ficcional" (Oliveira, 2006, p. 44). Para autora, a ficção modernista paulistana é marcada pela grande ausência do elemento imigrante. A explicação ofertada pela pesquisadora esbarra em argumentos já propostos por Fausto e aqui anunciados: a transformação dos italianos e descendentes em "ítalo-paulistas" arranhava o mito bandeirante original, de quem descendia o povo paulista, fruto da mescla entre o português e o indígena, mito que servia para legitimar em chave simbólica uma suposta supremacia da aristocracia paulista. A saída era "paulistanizar" o imigrante, ou seja, tratar de aculturá-lo de acordo com o imaginário dessa elite que sonhava descender de homens bravos e conquistadores destino que deveria ser reservado, de acordo com tal lógica obtusa, a São Paulo, o suposto carro-chefe da nação. A aculturação, até certo ponto, ocorreu, mas ficou reservada àqueles que chegaram à universidade, porção pouco generosa de uma elite de origem imigrante que conheceu a ascensão social e passou a rondar os círculos mais restritos da aristocracia paulista(na). Alguns procuraram asseverar o sucesso e torná-lo reconhecido a partir da reconversão do capital material em capital simbólico, procurando inserir-se no campo intelectual e buscando o status de "artista". E mesmo essa tímida fatia, nos propõe Oliveira, frequentava apenas as esferas culturais consideradas menores (Oliveira, 2006, p. 57) e mesmo nas altas rodas artístico-literárias, o estigma de imigrante pesava e gerava desconfortos, disputas e afastamentos (Miceli, 2003).

Além desse fator, soma-se ainda um outro que ajuda a explicar por que a realidade social do imigrante, tão importante para a história da capital paulistana, não encontrava uma representação ficcional à altura: a literatura modernista estava à procura de suas raízes nacionais e preocupada em fundar mitos de origem - inclusive, e principalmente, de São Paulo. A busca pela brasilidade, a ânsia em descobrir e revelar o Brasil "real" aos

Dossiê Literatura e Memória 
brasileiros, ressaltando o que temos de mais original e autêntico, inventando a arte e literatura brasileiras para se livrar da cópia importada, era este, em termos rudemente resumidos, o projeto modernista, e que acabava por gerar certa irritação diante da presença imigrante. Para Lúcia Lippi Oliveira, era flagrante o malestar de Mário de Andrade, tido como o maior líder do modernismo paulista ao lado de Oswald, diante dos imigrantes (Oliveira, 2006, p. 59). Tal mal-estar pode ser constatado em vários momentos da obra de Mário: o gigante comedor de gente, Venceslau Pietro Pietra, de Macunaíma, versão satírica do capitalista que não mede esforços para ganhar sempre; ou o artigo sobre arte que escrevera para a revista Terra Roxa e outras terras:

Tudo incultura, tudo superstição. Tudo estupidez de guarani apolainado, agravado pela boçalidade de estrangeiros mal transplantados, que gemendo de gratidão idiota e saudade idólatra pela pátria em que não conseguiram ganhar o pão, vêm envenenar a água da gente com uns Denzas, uns René Batons, uns edicéteras de porcaria, inomináveis (Andrade, Mário de apud Oliveira, 2006, p. 62)

Aqui, observa acertadamente Oliveira, damos de cara com o elitismo das vanguardas, que nega qualquer viés mais popular de uma classe média de origem estrangeira que começava a se formar, como se se apresentassem, para o gosto implacável de Mário de Andrade, como portadores de uma cultura ilegítima; os seus membros não estavam prontos ainda para pagar o pedágio necessário e ter acesso à "verdadeira" produção cultural nacional. Várias obras modernistas - o já citado Macunaíma, de Mário de

Dossiê Literatura e Memória

Arquivos do CMD, Volume 3 N.2. Ago/Dez 2015
Andrade; Martim Cererê (Cassiano Ricardo) e Cobra Norato (Raul Bopp) - ou apagaram a presença do imigrante ou retrataram-no de modo pejorativo, como uma espécie de resposta à "ameaça" que representavam.

Mas esta é apenas parte da história. O modernismo, como já se disse, não formava um todo homogêneo, mas era composto de muitos grupos, que ora se atraíam ora se repeliam, grupos em disputa e que se alinhavam. Diante de tal heterogeneidade não se podia esperar que o posicionamento modernista em relação à imigração não fosse ambíguo. No fundo, a ambiguidade revela as divergências e contradições do movimento, inclusive em relação a essa matéria, a imigração.

Paulo Prado, "o espírito aristocrático que dera identidade de classe ao modernismo" (Oliveira, 2006, p. 67), parece atualizar o mito bandeirante, negando a presença do negro, mas incorporando o imigrante. Na interpretação de Prado, São Paulo constitui o lugar do Brasil onde havia ocorrido uma "miscigenação correta", i.e., uma mistura racial que excluía o negro. O imigrante contribuiria, então, com toda sua herança cultural - além da "salvação" étnica, é claro - e, ao mesmo tempo, seria "abrasileirado" - melhor dizer, "paulistanizado" - pela "raça de gigantes" de São Paulo, sendo integrado à comunidade mais abrangente. A esse respeito, escreve Oliveira:

As contribuições das civilizações superiores, trazidas pelos imigrantes, seriam incorporadas sem que a nação alterasse sua identidade. Isso seria possível graças aos atributos originais superiores presentes no caráter paulista. E seu progresso, resultante de tudo 
7 “(...) o Bandeirante encarna bem, no imaginário das elites, a figura do desbravador, do pioneiro, daquele que, sem descanso, trabalha pelo enriquecimento do País. A metáfora é tão eficiente que acaba forjando uma identidade regional forte e duradoura. Entretanto, não se pode esquecer, a imagem por excelência do sucesso da oligarquia paulista é sua capital, São Paulo, expressão máxima do espírito empreendedor e progressista que $\mathrm{o}$ grupo pretende dar de si mesmo, da autoimagem construída e propalada. E o Bandeirante, representado e lembrado em referenciais espaciais precisos, dentro do espaço urbano, também está por trás da forma dada a esse espaço durante a grande urbanização Encarnado perfeitamente o agente da metropolização, ele toma parte ativa ideário dominante" (Schpun, 2003, p. 22). isso, deveria ser estendido ao restante do país, realizando uma espécie de 'benéfico imperialismo' (Oliveira, 2006, p. 74).

Nesta nova versão do bandeirantismo, São Paulo aparece como um lugar já habituado à mescla cultural por sua própria história, marcada por pioneiros acostumados ao contato interétnico, que traziam e adaptavam para as bandas de cá as mais divergentes influências culturais. Nesse sentido, São Paulo serviria como modelo para todo o país, pois ensinava as lições do caldeamento racial. O discurso intelectual paulista, a esta altura, apregoava que se havia um local que pudesse servir como "cadinho das raças", esse local era São Paulo. Daí, uma vez mais, a ideia de que a autêntica brasilidade se encontrava em paragens paulistas.

O modernismo via-se premido entre uma posição elitista mais ortodoxa, num certo sentido mais presa ao passado, e uma posição elitista um pouco mais heterodoxa, mais flexível em relação ao elemento estrangeiro. Tais ambiguidades se revelam em muitos momentos e de variada forma. Mário de Andrade, em seu Prefácio interessantíssimo, procurando justificar e explicar suas posições estéticas, admite: "Sou passadista, confesso. Ninguém pode se libertar duma só vez/das teorias-avós que bebeu (...)" (Andrade in Teles, 1983, p. 299; Andrade, 2003, p. 8-9). O passado se faz presente não apenas por meio da teoria e prática estética de Mário e outros companheiros de modernismo, mas também no assunto ora tratado, a imigração.
Embora reconheça as ambiguidades do autor e aponte, de modo pertinente, suas posições nacionalistas e antiestrangeiras, Oliveira parece carregar sua paleta de tons monocromáticos, enfatizando a todo momento o desconforto de Mário tocante aos imigrantes e se esquece de outros tons e meio tons que colorem a obra deste Andrade, contraditório em várias circunstâncias. Parece claro que Mário de Andrade se sentia pouco à vontade diante da verdadeira invasão italiana que tomou conta de São Paulo, mas, como escreve Carelli, a obra do autor "não se apresenta como um bloco monolítico, mas como um corpo vivo que não para de evoluir" (Carelli, 1985, p. 137). Essa outra posição, mais receptiva em relação à presença imigrante, não arrefece o mito do bandeirante paulista ${ }^{7}$, ao contrário, o fortalece, pois infla ainda mais a imagem de que é em São Paulo que ocorre, como pretendia Paulo Prado, a miscigenação "certa", de que São Paulo, a cidade, é cosmopolita, de que existe uma "paulistanidade" resultante do encontro étnico-cultural.

É sob essa óptica que pode ser lido o capítulo XIV, Muiraquitã, que trata da luta entre Macunaíma e o gigante Venceslau Pietro Pietra e a recuperação da pedra mágica cujo nome dá título ao capítulo. Há, em seu final, uma espécie de incorporação antropofágica do imigrante, representado pelo gigante Venceslau, cujo nome já indica qual sua origem - embora o autor, a certa altura do texto, o identifique como peruano -, operação simbólica responsável pela miscigenação "certa" que acima me referi, pois filtra os elementos culturais imigrantes e absorve apenas, digamos,

Dossiê Literatura e Memória 
os nutrientes necessários para a formação de uma cultura original e por isso saudável, que seria, nos termos propostos pelo modernismo de Mário de Andrade, a cultura paulista e paulistana, alçada à condição de cultura nacional:

Deu um arranco. Os espinhos ferraram na carne do gigante e o sangue espirrou. A Caapora lá embaixo não sabia que aquela sangueira era do gigante dela e aparava a chuva na macarronada. Molho engrossando.

- Para! Para! Piaimã gritava.

- Balançou até o gigante ficar bem tonto e então deu um arranco fortíssimo na japecanga. Era porque tinha comido cobra e estava furibundo. Venceslau Pietro Pietra caiu no buraco berrando cantando:

- Lem lem lem... si desta escapar, nunca mais como ninguém!

Enxergava a macarronada fumegando lá embaixo e berrou pra ela:

- Afasta que vos engulo!

Porém jacaré fastou? Nem tacho! O gigante caiu na macarronada fervendo e subiu no ar um cheiro tão forte de couro cozido que matou todos os ticoticos da cidade e o herói teve uma sapituca. Piaimã se debateu muito e já estava morre-não-morre. Num esforço gigantesco inda se ergueu no fundo do tacho. Afastou os macarrões que corriam na cara dele, revirou os olhos pro alto, lambeu a bigodeira:

\section{- FALTA QUEIJO! Exclamou...}

E faleceu.

Este foi o fim de Venceslau Pietro Pietra que era o gigante Piaimã comedor de gente.

Macunaíma quando voltou da sapituca foi buscar a muiraquitã e partiu na máquina bonde pra pensão. $\mathrm{E}$ chorava gemendo assim:

- Muiraquitã, muiraquitã de minha bela, vejo você mas não vejo ela!... (Andrade, 2007, p. 170; Andrade, 1989, p. 105-106)
A cena final do capítulo, acima reproduzida, deixa entrever algumas características do modernismo preconizado por Mário: o apetite antropofágico da cidade de São Paulo, que assimila as culturas imigrantes para criar a sua própria, expressa pela imagem do gigante comedor de gente transformado em comida, a macarronada, prato perfeitamente integrado aos hábitos alimentares do paulistano; o humor que não falta, nem mesmo em momentos decisivos e/ou trágicos, traduzido pela exclamação final de Venceslau, no momento de sua morte, que faltava queijo no molho da macarronada; humor este salpicado por alguma tristeza, que encontramos na fala de Macunaíma que encerra o capítulo, ao lamentar que a recuperação da pedra mágica não trouxe de volta seu antigo amor, como se assinalasse que o próprio modernismo ainda não havia encontrado sua formulação final, mais bem acabada, que o projeto era um processo contínuo. Esse estranho jogo que oscila entre humor/ironia/tristeza pode ser lido como um conjunto de contradições, ambiguidades, fragmentações que não tornam, na perspectiva mariodeandradiana, o modernismo paulista frágil, titubeante; ao contrário, denotam toda a riqueza, a potência, as possibilidades de um modernismo que privilegia os encontros e os diálogos interculturais que permitem a mistura de idiomas, sintaxes, gramáticas culturais as mais diversas, alimentando e sendo alimentada pela vida metropolitana de São Paulo, que, provavelmente para Mário de Andrade, era única no país e justamente por isso tornava a cidade símbolo e expressão da cultura nacional. 


\section{VIII.}

Como se alertou logo no início deste artigo, o que se pretende aqui é lançar hipóteses de trabalho a partir de uma constatação inicial no romance rapsódico de Mário de Andrade: São Paulo aparece justamente na metade do livro e é na cidade que se desenrolam episódios importantes, centrais da história. Por que isso acontece? Por que São Paulo e não outra cidade qualquer? Qual o sentido de tal arquitetura narrativa? Oferecer respostas provisórias a partir de uma visada sociologicamente orientada é o que pretendo aqui. E a hipótese mestra é a de que Macunaíma, o livro, não oferece apenas uma espécie de "herói civilizador", como indica a pesquisadora Eneida Maria de Souza (Souza, 1988, p. 296), mas apresenta São Paulo como foco irradiador da civilização modernista, pois é a cidade que reúne e sintetiza elementos culturais díspares dispersos por todo o Brasil, que abriga temporalidades e espacialidades históricas distintas, apesar de ser, no período, o Estado mais desenvolvido do país em termos econômicos e tecnológicos. Pode-se dizer que a condição periférica de São Paulo nos finais dos anos 1910 e começos dos 20 criou solo fértil para o esforço modernizador e modernista de suas elites, e tal modernidade periférica acabou produzindo uma modernização esteticamente avançada, mas politicamente conservadora, uma vez que o escopo - na arte e na política - era justamente conservar a hegemonia de São Paulo diante dos demais estados da nação - e sob a égide da elite aristocrática da cidade.
São Paulo, portanto, seria nada menos que a realização concreta, histórica de um sincretismo que Mário tanto buscava e valorizava em seu projeto estético modernista. Projeto que se encontrava em sintonia com os anseios e ambições políticas e econômicas das elites paulistanas mais arejadas, que se esforçavam em manter São Paulo como estado hegemônico da nação num momento - final dos anos 1920 - em que a importância do estado e da cidade declinava nos terrenos econômico, político e cultural. Nesse sentido, se Macunaíma representa, em alguma medida, o último respiro de uma das vertentes do modernismo paulista, decerto é o seu produto estético mais bem acabado, logo, um poderoso protocolo de leitura que procurava instituir uma leitura consagradora de um só modernismo e uma interpretação unívoca e dessacralizadora dos demais modernismos.

\section{IX.}

O projeto intelectual de Mário de Andrade, a despeito de toda sua singularidade, não deixou de se vincular a um projeto político e cultural ainda maior que pretendia firmar a posição hegemônica de São de Paulo (e de certa vertente de seu modernismo) no cenário nacional. Tal projeto tinha à frente as elites aristocráticas paulistas, nexo que o próprio Mário admite:

(...) o movimento modernista era nitidamente aristocrático. Pelo seu caráter de jogo arriscado, pelo seu espírito aventureiro ao extremo, pelo seu 


\begin{abstract}
internacionalismo modernista, pelo seu nacionalismo embrabecido, pela sua gratuidade antipopular, pelo seu dogmatismo prepotente, era uma aristocracia de espírito. Bem natural, pois, que a alta e a pequena burguesia o temessem. Paulo Prado, ao mesmo tempo que um dos expoentes da aristocracia intelectual paulista, era uma das figuras principais da nossa aristocracia tradicional. Não da aristocraci improvisada do Império, mas da outra mais antiga, justificada no trabalho secular da terra e oriunda de qualquer salteador europeu, que o critério monárquico do Deus-Rei já amancebara com a genealogia (Andrade, Mário de, 2002, p. 259).
\end{abstract}

Melhor diagnóstico, impossível. Ainda mais para alguém que se encontrava no centro dos acontecimentos. Mário percebia os vínculos entre a "aristocracia de espírito" representada pelos intelectuais modernistas e a "aristocracia tradicional", ainda com importância e poder políticos, responsável por erigir o mito bandeirante da potência paulista. $O$ que talvez Mário não percebesse é que seu próprio projeto criador satisfazia os anseios dessa elite tradicional, fornecendo a munição simbólica necessária para a produção difusão de tal imaginário. Como bem observou Joan Dassin (1978), modernismo e tradicionalismo conviviam confortavelmente nos salões mantidos pelos barões do café herdeiros, como o de Dona Olívia Guedes Penteado, à Rua Duque de Caxias (Dassim, 1978: 52). Aliás, frisa a mesma autora levando-se em consideração o estilo de vida das famílias rurais dominantes e suas pretensões políticas, não estranha que tivessem fornecido inspiração e apoio aos intelectuais modernistas (Idem, p. 61-62).
Para os dirigentes paulistas, escreve Sergio Miceli (2009: 166), as derrotas de 1930 e 1932 resultaram, em larga medida, da carência de profissionais no trabalho político e cultural. Daí os esforços encampados por tal camada para a formação de instituições culturais de alto nível: a Escola de Sociologia e Política (1933), a Faculdade de Filosofia, Ciências e Letras, no interior da recém-criada Universidade de São Paulo (1934), e o Departamento Municipal de Cultural, para o qual Mário de Andrade foi nomeado diretor em 1935 - não é possível não enxergar aí, mais uma vez, os nexos entre o seu projeto criador e as ambições e planos políticos mais abrangentes das elites locais, com os quais, podemos supor, Mário no mínimo simpatizava.

A obra de Mário de Andrade como um todo - e, aqui, Macunaíma, em particular - ajudou a construir a imagem de uma civilização modernista paulista, i.e., que tinha São Paulo como foco irradiador privilegiado de um certo modelo de civilização. Apenas São Paulo, por sua história, por sua composição étnico-cultural, por sua "cultura de mescla", por sua "miscigenação correta" - que, apesar da mestiçagem, colocava as coisas em seus devidos lugares - poderia servir de sustentáculo para a nação. Aliás, nesses termos, era em São Paulo que a nação começava. O projeto criador de Mário representava a síntese entre campo e cidade, entre o aristocrata tradicional e o industrial da cidade, entre o trabalhador rural e o urbano, entre a cultura europeia branca e a herança racial brasileira mista, entre o erudito e o popular. Todos esses contrastes, 
na obra de Mário, se encontravam e se resolviam, de algum modo, em São Paulo.

Se, por um lado, o projeto intelectual de Mário se voltava para a discussão e determinação de uma identidade nacional brasileira "intemporal", apoiada em tradições móveis e plurais, que negava uma espécie de essência universal, apoiado, portanto, num princípio estético de "desgeografização" ou da "desregionalização" (Carvalho, 2014, p. 342-334), por outro, Mário se esforçou igualmente para encontrar um "núcleo civilizatório" que representasse a possibilidade de concretização dum Brasil plural, mestiço, um lugar que sintetizasse a modernidade nacional. Nesse sentido, Mário opera, num segundo movimento, a "recartografização", a "regeografização" da cultura nacional, pois São Paulo constituía esse núcleo, pois servia de abrigo à sua "utopia geográfica".

E ainda que se esse esforço de síntese fosse concebido e implementado de maneira democrática, sem intolerância e preconceito, que o projeto criador mariodeandradiano se pautasse pelo pluralismo (Botelho, 2012; Carvalho, 2014), pelo "nacionalismo crítico", ainda assim não perde força a hipótese de que São Paulo, para Mário, representasse o lócus privilegiado dessa polifonia cultural: para ele, só em São Paulo um tupi poderia tanger um alaúde.

\section{Bibliografia:}

ARON, Paul \& VIALA, Alain. Sociologie de la Littérature. Paris: PUF, 2006.

ALVIM, Zuleika M. F. Brava Gente! São Paulo: Brasiliense, 1986. ANDRADE, Mário de. Macunaíma. Belo Horizonte: Itatiaia, 1989.

. Macunaíma. Rio de Janeiro: Agir, 2007.

. Aspectos da Literatura Brasileira. Belo Horizonte: Itatiaia,

2002

BOSI, Alfredo. "Situação de Macunaíma" In: ANDRADE, Mário de. Macunaíma. Coord. Telê Porto Ancona Lopez. Paris; Brasil: ALLCA XX: CNPq, 1988.

"O movimento modernista de Mário de Andrade". Literatura e Sociedade, São Paulo, n.7, p. 16-34, 2003/2004.

BOTELHO, André. De olho em Mário de Andrade. Uma descoberta intelectual e sentimental do Brasil. São Paulo: Claro Enigma, 2012.

BOURDIEU, Pierre. A Economia das Trocas Linguísticas. São Paulo: Edusp, 1998

. "L'identité et la représentation: eléments pour une réflexion critique sur l'idée de región". Actes de la Recherche en Sciences Sociales, n. 35, novembre 1980.

BRITO, Mário da Silva. "A revolução modernista" In: COUTINHO, Afrânio (org.). A Literatura no Brasil. A era modernista. São Paulo: Global, 2001.

CAMARGOS, Márcia. Villa Kyrial. Crônica da Belle Époque paulistana. São Paulo: Senac, 2001. 
CARDOSO, Zélia Ladeira Veras de Almeida. O Romance Paulista no Século XX. São Paulo: Academia Paulista de Letras, 1983.

CARELLI, Mário. Carcamanos e Comendadores. São Paulo; Ática, 1995.

CARVALHO, Fábio Almeida de. "Mário de Andrade, Macunaíma e interpretação do Brasil" In: CARVALHO, Fábio Almeida de \& EUGÊNIO, João Kennedy (orgs.). Interpretações do Brasil. Rio de Janeiro: E-papers, 2014

CENNI, Franco. Italianos no Brasil. São Paulo: Edusp, 2003.

CLAVAL, Paul. "Le thème regional dans la littérature française. L'Espace Géographique, tome XVI, no. 1, janvier/mars 1987, p. 60-73.

CRUZ, Heloisa de Faria (org.). São Paulo em Revista. São Paulo: Arquivo do Estado, 1997.

São Paulo em Papel e Tinta. Periodismo e vida urbana (1890-1915). São Paulo: Educ; Fapesp; Arquivo do Estado de São Paulo; Imprensa Oficial, 2001

DASSIN, Joan. Política e Poesia em Mário de Andrade. São Paulo: Duas Cidades, 1978.

DIEGUES Jr., Manuel. Imigração, Urbanização $e$ Industrialização. Rio de Janeiro: Centro Bras. Pesq. Educacionais, 1964.

FABRIS, Annateresa. "Modernidade e vanguarda: o caso brasileiro" In: (org.). Modernidade e Modernismo no Brasil. Campinas: Mercado Aberto, 1994.
FAUSTO, Boris. "Imigração e participação política na I República" In: et al. Imigração e Política em São Paulo. São Paulo: Sumaré/Fapesp, 1995

Historiografia da Imigração para São Paulo. São Paulo: Sumaré/Fapesp, 1991.

FERREIRA, Antonio Celso. A Epopéia Bandeirante: letrados, instituições, invenção histórica. São Paulo: Unesp, 2002.

- "Entre a tradição e a modernidade, entre a história e o romance". Revista do Instituto Histórico e Geográfico de São Paulo, v. XC, São Paulo, 1995.

FONSECA, Maria Augusta. "A carta pras icamiabas" In: ANDRADE, Mário de. Macunaíma. Coord. Telê Porto Ancona Lopez. Paris; Brasil: ALLCA XX: CNPq, 1988.

GRÜN, Roberto. “Os judeus na política paulista” In: FAUSTO, Boris et al. Imigração e Política em São Paulo. São Paulo: Sumaré/Fapesp, 1995.

HALL, Michael. "Imigrantes na cidade de São Paulo" In: PORTA, Paula (org.). História da Cidade de São Paulo. A cidade na primeira metade do século XX (1890-1954). São Paulo: Paz e Terra, 2004.

HARDMAN, Francisco Foot. "Antigos modernistas" In: NOVAES, Adauto (org.). Tempo e História. São Paulo: Cias. das Letras, 1996.

IANNI, Octavio. “A imigração italiana” In: Raça e Classes Sociais no Brasil. São Paulo: Brasiliense, 2004. 
LAHUERTA, Milton. "Os intelectuais e os anos 20: moderno, modernista, modernização" In: LORENZO, Helena Carvalho de \& COSTA, Wilma Peres da (orgs.). A Década de 1920 e as Origens do Brasil Moderno. São Paulo: Ed. Unesp, 1997.

LOBO, Eulália Maria Lahmeyer. "A imigração portuguesa e a mão-de-obra no Rio de Janeiro na Primeira República" In: SILVA, Sergio S. \& SZMRECSÁNYI, Tamás (orgs.). História Econômica da Primeira República. São Paulo: Hucitec/Edusp/Imprensa Oficial, 2002.

LOPEZ, Telê Porto Ancona. "Rapsódia e resistência" In: ANDRADE, Mário de. Macunaíma. Coord. Telê Porto Ancona Lopez. Paris; Brasil: ALLCA XX: CNPq, 1988.

MARTINS, Ana Luiza. Revistas em Revista. Imprensa e práticas culturais em tempos de República, São Paulo (1890-1922). São Paulo: Edusp, 2001

MARTINS, Wilson. O Modernismo. São Paulo: Cultrix, 1977. MICELI, Sergio. Intelectuais e Classe Dirigente no Brasil (19201945). São Paulo: Difel, 1979.

. Nacional Estrangeiro. São Paulo: Cia. das Letras, 2003.

"Experiência social e imaginário literário nos livros de estreia dos modernistas de São Paulo". Tempo Social, São Paulo, 16 (1), p. 167-207, jun. 2004.

. "Mário de Andrade: a invenção do moderno intelectual brasileiro" In: BOTELHO, André \& SCHWARCZ, Lilia Moritz (orgs.). Um Enigma Chamado Brasil. São Paulo: Cia. das Letras, 2009.

Dossiê Literatura e Memória

Arquivos do CMD, Volume 3 N.2. Ago/Dez 2015
MOISÉS, Massaud História da Literatura Brasileira: modernismo. São Paulo: Cultrix, 2001.

MORETTI, Franco. Atlas do Romance Europeu (1800-1900). São Paulo: Boitempo, 2003.

A Literatura Vista de Longe. Porto Alegre: Arquipélago Editorial, 2008

MORSE, Richard. Formação Histórica de São Paulo. São Paulo: Difel, 1970.

OLIVEIRA, Lúcia Lippi. "Os italianos, os bandeirantes e os modernistas paulistas" In Nós e Eles. Relações culturais entre brasileiros e imigrantes. Rio de Janeiro: Ed. FGV, 2006.

PASSIANI, Enio. Na Trilha do Jeca. Monteiro Lobato e a formação do campo literário no Brasil. Edusc: Bauru, 2003.

PINTO, Maria Inez Machado Borges. "Urbes industrializada: o modernismo e a pauliceia como ícone da brasilidade". Rev. Bras. Hist., São Paulo, v. 21, n. 42, 2001, p. 435-455.

POCOCK, Douglas C. D. "Geography and literature". Progress in Human Geography, 12 (1), 1988, p. 87-102.

PONTES, Heloísa. Destinos Mistos. São Paulo: Cia. das Letras, 1996.

ROCHA, João Cezar de Castro. "Sem nenhum caráter? A rapsódia de Mário de Andrade". In: CARVALHO, Fábio Almeida de \& EUGÊNIO, João Kennedy (orgs.). Interpretações do Brasil. Rio de Janeiro: E-papers, 2014 
SANTIAGO, Silviano. "A trajetória de um livro" In: ANDRADE, Mário de. Macunaíma. Coord. Telê Porto Ancona Lopez. Paris; Brasil: ALLCA XX: CNPq, 1988.

SARLO, Beatriz. Una Modernidad Periférica: Buenos Aires 1920 y 1930. Buenos Aires: Nueva Visión, 2003.

SCHPUN, Mônica Raisa. "Luzes e sombras da cidade (São Paulo na obra de Mário de Andrade)". Rev. Bras. Hist., São Paulo, v. 23, n. 46, 2003, p. 11-36.

SCHWARCZ, Lilia. “A construção de uma identidade paulista” In: BUENO, Eduardo (org.). Os Nascimentos de São Paulo. Rio de Janeiro: Ediouro, 2004.

SEVCENKO, Nicolau. "O renascimento modernista de São Paulo" In: BUENO, Eduardo (org.). Os Nascimentos de São Paulo. Rio de Janeiro: Ediouro, 2004.

SOUZA, Gilda de Mello. O Tupi e o Alaúde. São Paulo: Duas Cidades; Ed. 34, 2003.

SOUZA, Eneida Maria de. "A pedra mágica do discurso" In: ANDRADE, Mário de. Macunaíma. Coord. Telê Porto Ancona Lopez. Paris; Brasil: ALLCA XX: CNPq, 1988.

TELES, Gilberto Mendonça. Vanguarda Europeia e Modernismo Brasileiro. Petrópolis: Vozes, 1983.

WILLIAMS, Raymond. "Quando foi o modernismo?" Margem Esquerda, São Paulo, n. 6, set. 2005.

_. Política do Modernismo. São Paulo: Unesp, 2011. 